\title{
LOSS OF ACTIVITY DURING FRACTIONATION OF SOME HUMAN SPERMAGGLUTINATING SERA
}

\author{
B. BOETTCHER AND D. J. KAY \\ School of Biological Sciences, The Flinders University of South Australia, \\ Bedford Park, South Australia 5042 \\ (Received 19th May 1970, accepted 17th Fune 1971)
}

While studying spermagglutinating sera, a number of sera which were positive in a microagglutination test (Franklin \& Dukes, 1964), but which were negative in a macroscopic test in gelatin medium (Kibrick, Belding \& Merrill, 1952) were found (Boettcher, Kay, Rümke \& Wright, 1971). It appears that the agglutinins in these sera are not immunoglobulins (Boettcher \& Kay, 1969; Boettcher, Hay, Kay, Baldo \& Roberts, 1970). During procedures for fractionating these sera, much of the activity is often lost. One cause of the loss is dialysis. Sera, dialysed overnight against phosphate-buffered saline, have shown marked decreases in their spermagglutinating activities, though their haemagglutinating activities have been unaltered (Boettcher \& Kay, 1969; Boettcher et al., 1970).

Reported here are the results of experiments designed to determine whether the loss of activity is due to inactivation of spermagglutinins, or to the loss of an active agent through the dialysis membrane. In this work, the spermagglutination technique of Franklin \& Dukes (1964) was used, with dilutions being made with non-agglutinating human serum. The degree of spermagglutination is recorded as the number of agglutinates observed/100 motile, unagglutinated spermatozoa. Thus, a score of 26/100 indicates that twenty-six agglutinates, and 100 unagglutinated spermatozoa, were seen in a scan of the slide. A test is positive if a score of at least $6 / 100$ is obtained, since this approximates to the criterion of at least one agglutinate per high power microscopic field, as used by Franklin \& Dukes (1964).

The spermagglutinating serum, Rom, has been used in much of our work. It was collected more than 4 years ago and has been stored frozen. It has given clear head-to-head agglutinates with all semen specimens (more than 100) against which it has been tested.

The Rom serum was dialysed, in the cold, using $8 / 32$ in. cellulose casing dialysis tubing (Visking Co., Chicago, Illinois) against 2 litres of phosphatebuffered physiological saline $(0.15 \mathrm{M}, \mathrm{pH} 7 \cdot 1)$ which was changed night and morning for 7 days. After dialysis, the serum had lost all of its spermagglutinating activity (Table 1 ), but the haemagglutinating activity of the serum (anti-B titre $1 / 64$ ) was unchanged.

In two other experiments, $0.8 \mathrm{ml}$ of phosphate-buffered saline was enclosed in a dialysis sac which was completely immersed in $3 \mathrm{ml}$ of Rom serum, and $0.6 \mathrm{ml}$ of a non-agglutinating human serum in a dialysis sac was completely immersed in $3 \mathrm{ml}$ of Rom serum. In a similar manner, $0.6 \mathrm{ml}$ of non-agglutinat- 
ing serum was dialysed against $3 \mathrm{ml}$ of the same non-agglutinating serum. Dialysis was allowed to proceed for 7 days in the cold. After dialysis, the spermagglutinating activity of all solutions was investigated (Table 1). A sample of the spermagglutinating serum which had lost its activity during dialysis was mixed with an equal volume of the phosphate-buffered saline which had been dialysed against the spermagglutinating serum. The spermagglutinating activity of the resulting solution was tested (Table 1 ).

\section{TABLE 1}

SPERMAGGLUTINATION SGORES OF VARIOUS SOLUTIONS TESTED BY A MICROAGGLUTINATION TEGHNIQUE

\begin{tabular}{|c|c|c|c|c|}
\hline \multicolumn{2}{|r|}{ Solution } & \multirow{2}{*}{$\begin{array}{c}\text { Dilution } \\
\text { Undiluted } \\
1 / 2 \\
1 / 4 \\
1 / 8\end{array}$} & \multicolumn{2}{|c|}{$1 \mathrm{hr}{ }^{\text {Score after }} 4 \mathrm{hr}$} \\
\hline 1. & Rom serum & & $\begin{array}{r}15 / 100 \\
13 / 100 \\
4 / 100 \\
0 / 100\end{array}$ & $\begin{array}{l}33 / 100 \\
29 / 100 \\
26 / 100 \\
12 / 100\end{array}$ \\
\hline 2. & Kay serum & Undiluted & $1 / 100$ & $3 / 100$ \\
\hline 3. & $\begin{array}{l}\text { Rom serum dialysed against } \\
\text { many changes of phosphate- } \\
\text { buffered saline }\end{array}$ & $\begin{array}{l}\text { Undiluted } \\
1 / 2 \\
1 / 4 \\
1 / 8\end{array}$ & $\begin{array}{l}2 / 100 \\
0 / 100 \\
0 / 100 \\
0 / 100\end{array}$ & $\begin{array}{l}0 / 100 \\
1 / 100 \\
0 / 100 \\
0 / 100\end{array}$ \\
\hline $4(a)^{*}$ & $\begin{array}{l}\text { Saline from dialysis sac } \\
\text { surrounded by Rom serum }\end{array}$ & Undiluted & $\begin{array}{c}0 / 100 \\
\text { Motility affected }\end{array}$ & $\begin{array}{l}\text { No count, } \\
\text { sperm dead }\end{array}$ \\
\hline $4(b)$ & $\begin{array}{l}\text { Rom serum surrounding } \\
\text { dialysis sac containing } \\
\text { saline }\end{array}$ & $\begin{array}{c}\text { Undiluted } \\
1 / 2 \\
1 / 4 \\
1 / 8\end{array}$ & $\begin{array}{r}13 / 100 \\
4 / 100 \\
0 / 100 \\
0 / 100\end{array}$ & $\begin{array}{r}20 / 100 \\
17 / 100 \\
10 / 100 \\
6 / 100\end{array}$ \\
\hline $5(a)$ & $\begin{array}{l}\text { Kay serum from dialysis } \\
\text { sac surrounded by Rom serum }\end{array}$ & $\begin{array}{c}\text { Undiluted } \\
1 / 2 \\
1 / 4 \\
1 / 8\end{array}$ & $\begin{array}{r}10 / 100 \\
7 / 100 \\
3 / 100 \\
0 / 100\end{array}$ & $\begin{array}{r}20 / 100 \\
16 / 100 \\
10 / 100 \\
5 / 100\end{array}$ \\
\hline $5(b)$ & $\begin{array}{l}\text { Rom serum surrounding } \\
\text { dialysis sac containing } \\
\text { Kay serum }\end{array}$ & $\begin{array}{c}\text { Undiluted } \\
1 / 2 \\
1 / 4 \\
1 / 8\end{array}$ & $\begin{array}{r}12 / 100 \\
10 / 100 \\
4 / 100 \\
0 / 100\end{array}$ & $\begin{array}{r}40 / 100 \\
18 / 100 \\
10 / 100 \\
6 / 100\end{array}$ \\
\hline $6(a)$ & $\begin{array}{l}\text { Kay serum from dialysis } \\
\text { sac surrounded by Kay serum }\end{array}$ & Undiluted & $1 / 100$ & $3 / 100$ \\
\hline $6(b)$ & $\begin{array}{l}\text { Kay serum surrounding } \\
\text { dialysis sac containing } \\
\text { Kay serum }\end{array}$ & Undiluted & $1 / 100$ & $2 / 100$ \\
\hline 7. & $\begin{array}{l}\text { Rom serum which had lost } \\
\text { activity during dialysis }(3) \\
+ \text { phosphate-buffered saline } \\
\text { from dialysis sac (4a) }\end{array}$ & $\begin{array}{l}\text { Undiluted } \\
1 / 2 \\
1 / 4 \\
1 / 8\end{array}$ & $\begin{array}{l}9 / 100 \\
9 / 100 \\
1 / 100 \\
0 / 100\end{array}$ & $\begin{array}{r}14 / 100 \\
16 / 100 \\
6 / 100 \\
3 / 100\end{array}$ \\
\hline
\end{tabular}

* Solutions marked (a) and (b) are each part of the one experiment.

The spermagglutinating serum dialysed against phosphate-buffered saline in a dialysis sac lost some of its activity. The saline itself did not become spermagglutinating. When the saline was mixed with the agglutinating serum which had been dialysed until it had lost all activity, the solution then became spermagglutinating.

The non-agglutinating serum enclosed in the dialysis sac suspended in Rom serum became spermagglutinating during the procedure and the surrounding spermagglutinating serum had its activity reduced. 
This work has been repeated using the serum Rom, and comparable results have always been obtained. The same procedures have been carried out using two other spermagglutinating sera and, although the results have been similar, the loss of activity into saline or into non-agglutinating serum during dialysis has been less. The age of the Rom serum may contribute to the greater ease with which it loses activity during dialysis.

Since any piece of dialysis tubing contains pores of various sizes, the passage of spermagglutinating activity through a membrane with critical dialysis properties and regular pore size was investigated. Two $\mathrm{ml}$ of Rom serum were put into an Amicon Diaflo Ultrafiltration unit (Scientific Systems Division, Amicon Corporation, Lexington, Mass.) with a PM-30 membrane, which will not permit molecules with a mol. wt of greater than 30,000 to pass. Phosphatebuffered saline $(400 \mathrm{ml})$ was passed through the unit containing the serum under a pressure of $60 \mathrm{lb} / \mathrm{in}^{2}\left(\approx 414.0 \mathrm{kN} / \mathrm{m}^{2}\right)$. The solution which had passed through

TABLE 2

SPERMAGGLUTINATION SGORES OF A SERUM BEFORE AND AFTER ULTRAFILTRATION

\begin{tabular}{l|c|cc}
\hline \multicolumn{1}{c|}{ Solution } & Dilution & \multicolumn{2}{c}{ Score after } \\
\cline { 2 - 3 } & Undiluted & $20 / 100$ & $45 / 100$ \\
& $1 / 2$ & $10 / 100$ & $26 / 100$ \\
& $1 / 4$ & $6 / 100$ & $16 / 100$ \\
& $1 / 8$ & $1 / 100$ & $9 / 100$ \\
& $1 / 16$ & $0 / 100$ & $4 / 100$ \\
2. Non serum & Undiluted & $0 / 100$ & $1 / 100$ \\
3. Rom serum after ultra- & Undiluted & $8 / 100$ & $26 / 100$ \\
filtration & $1 / 2$ & $3 / 100$ & $15 / 100$ \\
& $1 / 4$ & $2 / 100$ & $16 / 100$ \\
& $1 / 8$ & $1 / 100$ & $10 / 100$ \\
4. Ultrafiltration filtrate & $1 / 16$ & $0 / 100$ & $4 / 100$ \\
& Undiluted & $1 / 100$ & $0 / 100$ \\
5. Non-agglutinating serum + & & Poor motility & Many dead \\
ultrafiltration filtrate & Undiluted & $7 / 100$ & $20 / 100$ \\
\hline
\end{tabular}

the membrane was freeze-dried, taken up in $10 \mathrm{ml}$ of distilled water and $5 \mathrm{ml}$ of the solution made from the filtrate was mixed with $1 \mathrm{ml}$ of human non-agglutinating serum. This mixture was allowed to stand in the cold for $1 \mathrm{hr}$, dialysed overnight against phosphate-buffered saline and subsequently reduced to a volume of $1 \mathrm{ml}$ by pressure dialysis in a collodion membrane, surrounded by phosphate-buffered saline. The other $5 \mathrm{ml}$ of filtrate was reduced to $1 \mathrm{ml}$ by pressure dialysis in a similar manner.

The spermagglutinating activities of Rom serum, the serum after ultrafiltration, the filtrate, and the filtrate added to a non-agglutinating serum, were determined (Table 2). The anti-B haemagglutinating activity of Rom serum before and after ultrafiltration was $1 / 64$.

It can be seen from Table 2 that the non-agglutinating serum acquired spermagglutinating activity when an extract of the filtrate from the spermagglutinating serum was added to it, though the filtrate extract itself was 
inactive. Since the membrane used will allow only molecules with a mol. wt of less than 30,000 to pass, it appears that the compound which has been able to cause the non-agglutinating serum to become spermagglutinating has such a mol. wt. There is no suggestion that immunoglobulins were able to pass through the membrane since none could be detected by immunodiffusion or immunoelectrophoresis. Further, there was no loss of haemagglutinating activity.

During fractionation on Sephadex G-200, the spermagglutinating activity of Rom serum was found in association with the first, macro-molecular, peak (Boettcher \& Kay, 1969; Boettcher et al., 1970). The present evidence suggests, however, that the activity is associated with a molecule small enough to pass through a dialysis membrane. The molecule is presumably not active by itself, since saline dialysed against Rom serum is not spermagglutinating. Thus, the spermagglutination appears to involve a compound of low molecular weight, which will pass through a dialysis membrane, and combine with a high molecular weight non-dialysable compound in the serum. Either compound, by itself, is inactive.

Since the results of fractionation of Rom serum by Sephadex G-200 gel filtration, DEAE cellulose chromatography and zone electrophoresis exactly parallel the results for another spermagglutinating serum with non-immunoglobulin agglutinins (Boettcher \& Kay, 1969), and because of the results presented here, it is considered that the agglutinins in Rom serum are not immunoglobulins. It has been suggested that they are steroids attached to a $\beta$-lipoprotein carrier (Boettcher \& Kay, 1969). However, ultracentrifugal preparation of $\beta$-lipoproteins in a sodium bromide solution of density $1.20 \mathrm{~g} / \mathrm{ml}$, using the method of Schultz, Shreffler \& Harvie (1968), has shown that the prepared $\beta$-lipoprotein fraction does not have spermagglutinating activity, whereas the infranatant has. Thus, the nature of the agglutinins is still not clear.

During attempted fractionations of serum Rom, and others with similar spermagglutinating properties, on Sepharose 6-B, all spermagglutinating activity has been lost but $A B O$ haemagglutinating activity has been retained. It seems possible that the small molecular weight compound active in spermagglutination becomes separated from the larger one during this procedure. It is known that some interaction can occur between steroid molecules and some gel filtration media (Burke, 1969)

These results pertain to sera which are spermagglutinating by the microagglutination technique. Other sera which have spermagglutinating immunoglobulins, active in the Kibrick technique (Kibrick et al., 1952), but not active in the microagglutination technique (Boettcher et al., 1971) do not show the behaviour described here.

This work was supported by a grant from the Population Council, New York.

\section{REFERENCES}

Boetrcher, B. \& KAY, D. J. (1969) Fractionation of a human sperm-agglutinating serum. Nature, Lond. 223, 737.

Boettcher, B., HAy, J., KAy, D. J., Baldo, B. A. \& Roberts, T. K. (1970) Spermagglutinating activity in some human sera. Int. F. Fert. 15, 143. 
BoztTcher, B., KAY, D. J., Rümke, P. \& WRight, L. E. (1971) Human sera containing immunoglobulin and non-immunoglobulin spermagglutinins. Biol. Reprod. (in press).

BURKe, C. W. (1969) Steroid adsorption to gel filtration media, and its prevention by serum. Biochim. biophys. Acta, 187, 564.

FrankLin, R. R. \& Dukes, C. D. (1964) Antispermatozoal antibody and unexplained infertility. Am. J. Obstet. Gynec. 89, 6.

Kibrick, S., Belding, D. L. \& Merrill, B. (1952) Methods for the detection of antibodies against mammalian spermatozoa. Fert. Steril. 3, 430.

Schultz, J. S., Shrerfler, D. C. \& HARVIE, N. R. (1968) Genetic and antigenic studies and partial purification of a human serum lipoprotein carrying the Lp antigenic determinant. Proc. natn. Acad. Sci. U.S.A. 61, 963. 